\title{
Annual Reports
}

\section{Steering I}

The Treasurer's Report given by Mike Smith was presented and discussed. Following discussion regarding the Rozkuszka Scholarship, the Awards Committee was asked to explore the balance between GODORT resources and appropriate scholarship awards, and bring forward proposals for discussion.

GODORT Councilor Bill Sudduth reported on proposed resolutions circulating on the Council list, including memorial resolutions and the United Nations resolution.

Old Business included discussion of the Implementation Plan for GODORT Reorganization. If a committee or task force has not yet submitted their five year goals they should do so as soon as they are able, and the goals will be integrated into the planning. "Working draft" documents (such as the mission and major themes) will be refined before being put to a Membership vote. Membership will have opportunities to be involved in the revisions.

The Steering groups currently working on identifying goals to go with each theme will dissolve at the end of Steering II this conference. This work will be gathered and passed along to the 2016-17 Steering committee to continue. Steering broke into the subgroups working on the themes and worked on their plans for the rest of the meeting.

\section{GODORT General Membership Meeting}

Treasurer Mike Smith reported on GODORT's current financial standing. Royalties from the Serial Set book have now been paid to GODORT. The change of $D t t P$ from print to electronic distribution will reduce the continuing expenses of publishing DttP. Last year's recipient of the ProQuest/GODORT/ALA "Documents to the People" award was the Federal Reserve Bank of St. Louis. The award includes $\$ 3,000$, which they are prohibited from accepting. Proquest will instead donate money to GODORT to defray the production cost of this year's awards (\$300) and then will donate the remaining $\$ 2,700$ to the Rozkuszka Scholarship Endowment Fund.

Councilor Bill Sudduth reported that GODORT's resolution on the United Nations Depository Program was included in the ALA International Relations Committee Report, and was passed by ALA Council.

On behalf of the Federal Documents Task Force, Justin Otto requested that Steering work to change the name and focus of FDTF to Federal Information Interest Group. This will require new Bylaws language to Article VIII that discusses the types of groups within GODORT. Ultimately, membership would need to vote for this change to occur. FDTF specifically looked at the option of using the term "discussion group" and decided against it in favor of the (they felt more inclusive) term "interest group."

Shari Laster, incoming chair of the Program Committee, requested that committees and task forces submit program proposals as soon as possible.

Lynda Kellam, chair of the Awards Committee, announced that GLBRT and GODORT worked together to create a Mentorship Award in honor of Larry Romans. Work on this will become part of the Awards Committee's responsibilities.

Valerie Glenn, chair of the Publications Committee, reminded everyone that the last print issue of $D t t P$ is this Summer. Beginning September 1, DttP will be disseminated solely in electronic format. The files will be at journals.ala.org/dttp. Articles will be much more discoverable.

The current working plan for GODORT's reorganization has four phases:

1. Using the five programmatic themes from the reorganization report: Programming, Community, Education and Training, Advocacy, and Scholarship, along with a sixth theme, Administration, Steering has developed a working mission statement, then developed scope notes for each theme.

2. The list of goals developed by each task force and committee will be sorted under each of the themes.

3. The goals will be evaluated to determine what is possible and realistic based on available people and resources.

4. Goals that are identified as a priority will be mapped to programmatic areas they are invested in, to determine how units are going to function.

At this point, we are beginning on phase 2. Goals embedded in the historical Policies and Procedures Manual (PPM) and developed by the task forces and committees are being sorted into the themes.

Virtual meetings will be incorporated into the reorganization because member 
feedback was that many cannot afford to attend two national conventions a year. GODORT purchased a subscription to Adobe Connect. We need to develop the leaders and the expertise to lead virtual meetings and get collaboration from members who are not able to attend "breathing the same air" meetings.

Because of questions during the meeting, GODORT Chair Stephen Woods indicated that he will work with individual members to help them identify ways to participate when technology is a barrier. $\mathrm{He}$ also said that Steering Committee meetings are not recorded at this time but they are open to the public and the chat transcripts are available.

Finally, those at the gathering thought and spoke about Kathy Tezla, Carolyn Willa Kohler, and Larry Romans. They will be missed. Stephanie Braunstein led a memorial discussion.

\section{Steering II}

GODORT's Councilor Bill Sudduth reported that the ALA Council International Relations Committee (IRC) presented their report to Council, and the UN resolution passed unanimously.

Susan Patterson, International Documents Task Force (IDTF) coordinator, observed that one issue regarding the $\mathrm{UN}$ is the move from tiered to personalized pricing. This diminishes transparency and is a significant problem. Partly because of the change in pricing model, there are different ideas about the prices listed in the resolution. She also thanked Bernadine Abbott Hoduski and Shari Laster for all their help on the resolution and the process of seeing it through ALA. Steering expressed its appreciation to Susan Patterson and her collaborators for the successful resolution.

At the request of Justin Otto, Federal Documents Task Force (FDTF) coordinator, Steering discussed appropriate actions for changing the "task force" designation to "interest group." While the term "interest group" was used in the GODORT Reorganization Report (http://connect.ala.org/node/241840) it is not defined in GODORT Bylaws or PPM. Chair Stephen Woods asked the three task forces to collaborate on definitions and language that could then be brought to Steering for consideration. If approved, these changes would be voted on as a bylaws revision through the ALA election process.

The Preservation Working Group has produced three policy papers:

- "Collection of Federal Government Publications Must Be Preserved for the Use of the American People."

- "Government Publications Librarians_-Valuable Link Between Government Information Publishers and the Public."

- "Preservation of Federal Government Publications in Multiple Formats Proposal, Historic."

The first two were published in DttP; Steering agreed that the third should be published there as well.

GODORT Legislation met with the ALA Committee on Legislation's Government Information Subcommittee to work on a resolution regarding funding for preservation. Steering voted to accept Samantha Hager as GODORT's virtual meeting coordinator. Professor Jim Walther at Emporia State University will also work with GODORT on virtual meetings.

\section{Federal Documents Task Force (FDTF)}

FDTF discussed and approved the fiveyear goals for the group. They will be finalized and transmitted to Steering as part of GODORT's strategic planning process.

FDTF is putting forth an action item for Steering II to consider changing the name of FDTF to the "Federal Information Interest Group," or FIIG. FDTF will work on proposing changes to the bylaws to include the term "interest group." The discussion consensus was that "interest group" is a more inclusive and welcoming term than "discussion group" and is more aligned with terminology used in other units of ALA. Additionally, members felt that the term "interest group" would be a better term to use to make non-GODORT members to feel welcome to attend and participate.

The FDTF meeting concluded with a discussion of experiences with electronic documents in their FDL collections entitled "The all-digital, or nearly all-digital, depository."

—Justin Otto, FDTF Coordinator

\section{State and Local Documents Task Force (SLDTF)}

Jennifer Boettcher (Georgetown University) is looking for sponsorship for a possible Midwinter Deep Dive: "Where Does the Library Fit? Understanding Local Public Finance." The Deep Dive aims to teach library staff how to understand their local budgets and how the library's budget gets allocated. Priority goes to applicants with endorsements 
across ALA. Jane Canfield, incoming SLDTF coordinator-elect, will take the proposal to the Program Committee for review. Major questions include the timing of the workshop (Midwinter Meeting versus Annual Conference) and the level of involvement from SLDTF (e.g., sponsorship in name only, provide speakers).

SLDTF also discussed its five-year goals. Concern over preservation of state and local documents came up, which raised the question, "How best can task forces work with other committees such as REGP?" The major GODORT themes overlap in some ways. For example, working with a program submission might include both advocacy and programming. Also, we need to start modeling behavior online and consider that SLDTF will meet virtually for Midwinter Meetings and coordinate with committees over email.

—Jennifer Huck, SLDTF Coordinator

\section{International Documents Task Force (IDTF)}

IDTF discussed the GODORT resolution on the Restoration of the United Nations Depository Program. The discussion was for information purposes only and no vote needed to be made as it's already been accepted by IRC and will be brought up at ALA Council for review there. This is a time-sensitive issue and needs to be acted on.

The group also voted and accepted the IDTF five-year goals:

- Improve and promote access to international and foreign national information resources.

- Provide an arena for the exchange of information about new publications, projects, electronic products, internet sites and government initiatives in information.

- Advocate for the preservation for materials.

- Promote the use of these information resources and to improve their management through education and training, including participation in GODORT preconference's and program.

—Susan Paterson, IDTF Coordinator

\section{Awards Committee}

The GODORT Awards Committee congratulates the winners of its 2016 awards (http://wikis.ala.org/godort/index.php/ Announcing_the_2016_GODORT _Awards_Winners):

- James Bennett Childs Award: Helen M. Sheehy

- ProQuest/GODORTIALA "Documents to the People" Award: Federal Reserve Bank of St. Louis (St. Louis Fed) and Katrina Stierholz

- Bernadine Abbott Hoduski Founders Award: Alan Zoellner

- Margaret T. Lane /Virginia F. Saunders Memorial Research Award: Dr. Adam Rothman

- W. David Rozkuszka Scholarship: Julie Wagner

We have an excellent group of colleagues working with government information!

We will be adding a new award this year with the ALA Awards Committee's approval of the Larry Romans Mentorship Award administered jointly by GODORT and GLBTRT (Gay, Lesbian, Bisexual, and Transgender Round Table). This award will be a fitting memorial to Larry Romans and his commitment to mentoring new librarians both in government documents and the wider library profession. We encourage our membership to nominate eligible colleagues for this award as well as for all of our awards. Read more about each award and its requirements on our GODORT wiki page (http://wikis.ala.org/godort /index.php/AboutAwards).

—Lynda Kellam, Chair

\section{Bylaws and Organization Com- mittee}

The GODORT Bylaws and Organization Committee met as scheduled; however, the only attendee present was the committee chair. Therefore the committee did not hold a meeting, nor discuss the agenda items previously posted to ALA Connect by the committee chair.

—David Utz, Chair

\section{Cataloging Committee}

The Cataloging Committee discussed several reports from vendors and liaisons. These included reports from the Government Printing Office (GPO) (Donna Kraemer), MARCIVE (Jim Noel), HathiTrust/Registry for US Federal Documents (Valerie Glenn), the State and Local Documents Task Force (Simon Healey), and the International Task Force (Michael Alguire).

There was an update on the GODORT reorganization and a discussion on the project to review, update, and revise the Cataloging committee's mission and goals for the next five years. The committee completed its work in February and submitted its report to the Steering Committee for use during the ongoing work of reorganization. In addition, there was discussion on what goals and tasks the Cataloging Committee might 
work on in 2016-17. This included a brief report by Andrea Morrison, Toolbox editor, concerning the plans to update the Toolboxes for Processing and Cataloging Federal, State and Local, and International Government Documents on the GODORT wiki.

There were questions raised concerning PURLs and "closed caption" information in bibliographic records. The first question concerned PURLs created by the GPO that are no longer active and the revamped FDLP PURL Usage Report. The release of the revamped report is expected soon. The second question concerned whether "accessibility," such as "closed captions," could be recorded. Accessibility content should be described according to RDA 7.14 (and any appropriate LC-PCC PS), and recorded in MARC field 546. There are several best practices documents for cataloging and coding DVDs, streaming media, and video language that can be found on the OLAC (Online Audiovisual Cataloging) website (http://olacinc .org).

_Ellen Caplan, Chair

\section{Education Committee}

The GODORT Education Committee discussed the committee charge and goals, which were drafted at the virtual Midwinter Meeting. The charge will be voted on by the committee and sent to the ByLaws Committee for inclusion in the PPM if approved, and the committee reaffirmed the priority of revising the competencies to include clearer information specifically for generalists and school and public librarians. The committee also discussed proposing two programs over the next five years and doing a thorough update of the GODORT Exchange.
—Karen Hogenboom, Chair

\section{Government Information for Children (GIC) Committee}

The Government Information for Children (GIC) Meeting at ALA Annual 2016 in Orlando was a productive and lively forum for a discussion of "all things government information from the child point of view-POV."

Excellent progress is being made relative to the GIC Clearinghouse (LibGuide) (http://guides.ucf.edu/gic) with the status of current updates and proposed enhancements and additions as key discussion points. These include

- Spanish-language LibGuides page to include government agency links in Spanish and notable Spanish government documents;

- State pages, with links being added in the LibGuides to individual state pages, developed in concert with the State Agency Databases project (http://wikis.ala.org/godort/index.php /State_Agency_Databases) to identify possible resources to transfer and an editing production process as it relates to the GIC Clearinghouse; and

- GIC Clearinghouse publicity to promote awareness and use. The intended audiences are school librarians, teachers, and parents. The publicity piece will be a simple handout to email that can be shared with listservs, organizations, and at conferences.

Another important GIC project is National History Day (NHD), the annual celebration of history education in the United States (http://nhd.org/ about-us). Amy Riegelman (University of Minnesota) who served as the NHD liaison for several years, finished her service prior to the 2016 Annual Conference. The first task of the new NHD liaison will be to obtain a list of the NHD regional directors (educators in each state who coordinate state and local contests) so that the GIC can develop joint publicity plans with them.

Additionally, as a related NHD effort, an effort is underway to revisit past connections with NoodleTools (a research citation firm and NHD sponsor) and the Government Information Online: Ask A Librarian (http://govtinfo.org). GIC members are interested in developing a permanent relationship with them to assist NHD participants in answering government information questions that arise in the course of their research.

Furthermore, the Constitution Day Poster Contest (www.constitutionfacts.com/ constitution-poster-design-contest), a GIC anchor activity, was reviewed. The 2015 contest attracted nearly 33,000 entries worldwide. Since the GIC is a co-sponsor and assists Constitutionfacts .com in reaching out to participating populations to promote the contest, all GIC committee members will reach out to their education departments and local schools to let them know about the 2016 Constitution Day Poster Contest.

Officials at Constitutionfacts.com will be contacted to make sure they have the GIC Clearinghouse link on Constitu tionfacts.com.

Additionally, the idea of Constitution Day/National History Day and other GIC initiatives to Steering and report results at the 2017 Midwinter Meeting. Also, GIC representatives will contact the GPO to see if they want to produce several FDLP Academy webinars on 
Constitution Day (various topics and languages).

Finally, prior to 2017 Midwinter, GIC members will brainstorm to identify ways to deliver useful Constitution Day information to teachers at the end of the current school year so that students may consider ideas and begin preparations over the summer. The result is that students will be prepared to participate once the new school year begins and have their individual projects ready to submit for consideration by the October 1 deadline.

—Tom Adamich, Co-Chair

\section{Legislation Committee}

GODORT Legislation Committee met with the Committee on Legislation Government Information Subcommittee (COL-GIS) Government Information Committee. Cindy Etkin of GPO reported on the regional depository libraries disposal proposal. Judy Russell reported on the attempt by Senator Claire McCaskill (D-MO) to shut down National Technical Information Service (NTIS). She has not changed her mind but has agreed that the collection should be saved and sent somewhere for maintenance and access. Senator McCaskill, who sponsored the bill to shut down NTIS, has agreed that the collection should be saved by someone, but still wants NTIS eliminated.

There was a lengthy discussion on funding for preservation of federal government publications. It was agreed that the two committees would work on a resolution for midwinter. The proposed seminar on preservation for June 2017 was discussed and COL-GIS will participate in the panel. Judy Russell agreed to participate in seminar to report on their work on preservation including last copy identification and preservation.

At the Legislation Committee II, the committee continued the discussion on a preservation resolution and pre-conference seminar. The GODORT Legislation Committee also indicated GODORT's support for the resolution honoring Mary Alice Baish upon her retirement as superintendent of documents.

— Bernadine Abbott Hoduski, Past Chair

\section{Membership Committee}

The Membership Committee hosted a GODORT 101 session on Friday, June 24 , in lieu of a meeting. To a standingroom-only crowd, current and incoming chairs and coordinators, including Stephen Woods, Karen Hogenboom, Siu Min Yu, Jenn Huck, Justin Otto, Shari Laster, Susan Paterson, Ellen Caplan, Valerie Glenn, Laura Sare, Rachel Dobkin, Lynda Kellam, and Lucia Orlando, as well as other GODORT members in attendance, spoke about the history, current projects, and vision of GODORT, as well as the benefits of joining. Several new and potential members made connections, signed on for committee work and attended subsequent GODORT events. After the session, we moved to the hotel lobby bar for a lively happy hour.

The Membership Committee provided promotional materials for the GODORT 101, General Membership Meeting, and the ALA Membership Pavilion: government poster magnets designed by Rebecca Hyde, a list of the government information-related sessions and exhibitors, a "GODORT Guide" of government resources related to voter registration, rights and education, and assorted GPO giveaways.

In addition to GODORT meetings, a Membership Committee representative attended the in ALA Membership Promotion Taskforce meeting, making connections for future interdivision collaboration.

—Rachel Dobkin, Co-Chair

\section{Nominating Committee}

The Nominating Committee would like to announce the following election results:

- Assistant Chair/Chair-Elect: Shari Laster

- Secretary: Laura Sare

- Publications Committee Chair/ChairElect: Robbie Sittel

- Awards Committee: Adam Clemons, Ann Marshall, Rebecca Hyde

- Bylaws Committee: Rory Elliot, Melanie Sims

- Nominating Committee: Julia Frankosky, Richard Mikulski

- Federal Documents Task Force Assistant Coordinator/Coordinator-Elect: Justin Otto

- International Documents Task Force Assistant Coordinator/CoordinatorElect: Catherine McGoveran

- State and Local Documents Task Force Assistant Coordinator/CoordinatorElect: Jane Canfield

- Councilor: Bill Sudduth

Congratulations to those elected!

—Laura Sare, Chair

\section{Program Committee}

GODORT co-hosted a preconference with MAGIRT (Map and Geospatial Information Round Table), "Making 
Sense of Data through Visualization.” The event, which was held at the University of Central Florida, was attended by nearly thirty participants. The hands-on training gave participants access to visualization tools and techniques. Additional information, including program slides, may be found at https://magirtgo dort.wordpress.com.

GODORT sponsored the program "Government Data Centers: A Look Under the Hood," a timely topic on accessing government data sets, which drew in social sciences and data services librarians. GODORT also co-sponsored the program "Saving Collections, Sharing Expertise: The FIPnet Collaboration across Library Specialties," with the Associaton for Library Collections and Technical Services (ALCTS). Jeanne Drewes from the Library of Congress, David Walls from the GPO, and Tamara Zavinksi from New York State Archives, spoke about the GPO's Federal Information Preservation Network (FIPNet).

The GODORT Program Committee met on July 14. We approved co-sponsoring a Deep Dive workshop on local government finance and libraries. This event will include hands-on training on how to use data from the Census of Governments during the 2017 Midwinter Meeting in Atlanta. Technically it is not a program but a new type of session ALA is trying out to provide more continuing education during Midwinter.

For the GODORT Annual Program, the Program Committee is working with the Preservation Working Group on a program about preservation of government information.

—Sarah Erekson, Chair

\section{Publications Committee}

DttP will become an electronic-only publication beginning in September. The URL will be https://journals.ala.org /dttp.

The committee approved a proposal to reinvigorate the GODORT Occasional Papers Series. Over the next year, we will

1. review and revise the guidelines for the series;

2. plan additional outreach and promotion for the series;

3. conduct a pilot during the 201617 academic year using this new approach; and

4. assess in the fall of 2017.

_Valerie Glenn, Chair

\section{Rare and Endangered Govern- ment Publications (REGP) Com- mittee}

REGP hosted a panel discussion instead of a regular business meeting. The main topic of discussion was the GPO's recently released "National Plan for Access to U.S. Government Information.” Serving on the panel were Daniel Cornwall, Kirsten Clark, and Shari Laster. Points of discussion focused on whether the federal government can guarantee the preservation of all government information; is digital deposit by depository libraries a viable option; can depositories ensure preservation of their tangible collections while still providing access to users; and what are the possible pros and cons of GPO's new Regional Discard Policy. The program was well attended.

_-Vicki Tate, Incoming Chair

\section{Preservation Working Group}

The Preservation Working Group presented its final report, included in whole on page 28 of this issue.

—Bernadine Abbott Hoduski, Chair 